\title{
ANALISIS DISPOSISI MATEMATIKA BERDASARKAN HIGHER ORDER THINKING TAKSONOMI BLOOM (Studi Kasus Mahasiswa Pendidikan Matematika Universitas Muhammadiyah Cirebon)
}

\author{
Desy Lusiyana ${ }^{1}$ \\ ${ }^{1}$ Universitas Muhammadiyah Cirebon
}

\begin{abstract}
Abstrak
Disposisi matematika sebaiknya diperhatikan pada proses pembelajaran. Tujuan Penelitian ini yaitu untuk mengetahui disposisi yang dimiliki oleh mahasiswa dalam berfikir Higher Order Thinking (HOT). Disposisi matematika yang diteliti yaitu disposisi matematika mahasiswa berfikir tingkat tinggi (higher order thinking), sehingga dengan mengetahui sikap dan tingkat berfikir mahasiswa memudahkan pendidik untuk membuat perangkat pembelajaran baik bahan ajar, alat peraga serta metode yang tepat dan bermakna. Metode yang digunakan pada penelitian ini yaitu kualitatif dan kuantitatif. Pengumpulan data digunakan yaitu tes dan angket. Berdasarkan analisis diperoleh sig $1.6 \%$. Hasil analisis data menunjukkan bahwa terdapat perbedaan disposisi matematika berdasarkan tingkat berfikir mahasiswa berdasarkan HOT dan disposisi matematika yang lebih dominan yaitu kepercayaan diri dan apresiasi peran. Sehingga diperoleh kesimpulan semakin tinggi tingkat berfikir mahasiswa maka semakin banyak disposisi matematika yang dimiliki.
\end{abstract}

Kata kunci: disposisi matetaik, berpikir tingkat tinggi, taksonomi

\begin{abstract}
Mathematical dispositions should be considered in learning process. The purpose of this study is to determine the disposition possessed by students in thinking Higher Order Thinking (HOT). The mathematical disposition studied is the student's high-order thinking mathematical disposition, so knowing students' attitudes and levels makes it easy for educators to make learning tools both teaching materials, teaching aids and appropriate and meaningful methods. The method used in this study is qualitative and quantitative. Data collection is used namely tests and questionnaires. Based on the analysis obtained sig $1.6 \%$. The results of data analysis showed that there were differences in mathematical dispositions based on students' level of thinking based on HOT and a more dominant mathematical disposition, namely selfconfidence and role appreciation. So that it can be concluded that the higher the level of thinking of students, the more mathematical dispositions they have.
\end{abstract}

Key words: Mathematical Disposition, Higher Order Thinking, Taxonomy 


\section{PENDAHULUAN}

Proses pembelajaran diperlukan suatu evaluasi. Evaluasi tersebut meliputi evaluasi aspek kognitif, afektif dan psikomotorik. Bloom, et al (1956: 7) membagi domain pembelajaran menjadi tiga bagian, yaitu domain kognitif, domain afektif, dan domain psikomotorik. Domain kognitif terdiri atas mengingat atau pemahaman pengetahuan dan perkembangan kemampuan serta keterampilan intelektual). Revisi dari taksonomi Bloom (Andersondan Krathwohl, 2002:213) membuat taksonomi pada ranah kognitif yang diklasifikasikan dalam 6 kategori yaitu pengetahuan, pemahaman,peerapan, analisis,sintesis, dan evaluasi. Anderson dan Krathwohl (2002: 65) merevisi taksonomi mencakup pada ranah kognitif yang dibuat oleh Bloom menjadi kategori mengingat, pemahaman, penerapan, analisis, evaluasi dan kreasi. Proses evaluasi pada proses berfikir diperlukan. menurut Maharaj, A., dam Wagh, V. (2016 :1) pada penelitiannya memperoleh hasil $37 \%$ peserta tidak memberikan tanggapan terhadap tugas yang disusun sesuai Higher order Thinking Skiil (HOTS).

Berdasarkan penelitian Maharaj, A., dan Wagh, V. (2016:1) (2016:1) disarankan untuk membiasakan membiasakan dan melatih HOTS di kalangan mahasiswa. Penelitian yang dilakukan di universitas pada mata kuliah kalkulus. Jadi pola berfikir HOT bukan lagi menjadi sesuatu yang baru. Tetapi harus sudah terbiasa dilakukan pada proses pembelajaran. Pembiasaan ini dilakukan mulai dari penyususnan perangkat pembelajaran sampai pada evaluasi. HOT merupakan proses berfikir pada ranah kognitif. Pada proses pembelajaran selain kognitif diperlukan aspek afektif. Disposisi matematika merupakan sikap positif seseorang terhadap matematika. Pada proses pembelajaran dikampus tiga aspek diatas harus terdapat dalam pembelajaran.

Universitas Muhammadiyah Cirebon merupakan universitas yang telah menerapkan kurikulum nasional. Perangkat pembelajaran dimuat sesuai dengan capaian pembelajaran. Capaian pembelajaran yang mencakup sikap, pengetahuan dan keterampilan. Berbeda dengan kurikulum sebelumnya, dari ketiga aspek hanya aspek pengetahuan yang diukur. Salah satu prodi yang terdapaat di universitas Muhammadiyah yaitu prodi pendidikan matematika. Salah satu mata kuliah yang wajib diampu yaitu geometri analitik.

Geometri analitik merupakan salah satu mata kuliah wajib ditempuh oleh mahasiswa program pendidikan matematika. Berdasarkan studi pendahuluan di 
Universitas Muhammadiyah Cirebon diperoleh hasil UTS diperoleh 36\% yang mendapat nilai diatas 65 dan sisanya dibawah nilai 50. Hasil UAS pada studi pendahuluan diperoleh $23 \%$ memperoleh nilai diatas 70 dan sisanya dibawah nilai 70 .

Berdasarkan studi pendahuluan tersebut ditemukan beberapa masalah dalam proses pembelajaran. Masalah dalam pembelajaran geometri berdasarkan studi pendahuluan yaitu kurangnya referensi belajar yang sesuai dengan tingkat berfikir mahasiswa, materi geometri yang bersifat abstrak dan belum maksimal penggunaan software geometri yang membantu memudahkan pemahaman geometri.

Hasil observasi merupakan hasil belajar melalui aspek kognitif. Oleh karena itu perlu dilakukan penelitian lanjutan yaitu pada aspek afektif. Aspek sikap yang akan diteliti yaitu disposisi matematika. Disposisi matematika tolak ukur untuk mengukur sikap matematika siswa. Pada penelitian ini akan diteliti level disposisi mahasiswa yang memiliki pola pikir Higher Order thinking. Menurut Bookhart (2010: 3) menjabarkan berpikir tingkat tinggi ke dalam 3 kategori yaitu transfer, berpikir kritis, dan pemecahan masalah. Sedangkan Resnick (1992:3) mendefinisikan kata kunci yang dapat mendeskripsikan berpikir tingkat tinggi antara lain dalam proses mengerjakan tidak algoritmik, maksudnya adalah algoritma pengerjaan tidak langsung ditentukan di awal memiliki beberapa jawaban yang memiliki manfaat masing- masing dan bukan merupakan jawaban yang unik penerapan dari beberapa kriteria yang terkadang saling bertentangan satu sama lain, melibatkan penilaian dan interpretasinya; dan kemandirian proses berpikir. Sedangkan Brookhart (2010) mengkategorikan HOT pada taksonomi Bloom pada tiga kategori teratas yaitu analisis, evaluasi dan kreasi. HOT pada penelitian ini yaitu HOT pada taksonomi Bloom.

Hasil pengamatan level disposisi matematika pada mahasiswa yang memiliki higher order thinking akan menjadi dasar membuat buku ajar geometri analitik berdasarkan higher order thinking berbasis disposisi matematika.

Berdasarkan latar belakang masalah yang diuraikan di atas, dirumuskan permasalahan sebagai berikut:

1. Apakah terdapat perbedaan antara mahasiswa yang memiliki kemampuan higher order thinking dan lower oerder thinking?

2. Apakah disposisi matematika dominan dimiliki mahasiswa yang memiliki kemampuan higher order thinking taksonomi Bloom? 
Tujuan dari peneliti ini yaitu:

1. Mengetahui perbedaan anatar mahasiswa yang memiliki kemampuan higher order thinking dan lower order thinking.

2. Mengetahui disposisi matematika yang dominan dimiliki mahasiswa yang memiliki kemampuan higher order thinking.

\section{METODE PENELITIAN}

Metode penelitian pada penelitian ini adalah penelitian kuantitatif dan kualitatif. Analisis kuanlitatif digunakan untuk membandingkan disposisi matematika pada tingkat berfikir mahasiswa. Analisis kualitatif untuk memetakan disposisi yang dominan dimiliki mahasiswa yang berfikir tingkat tinggi. Penelitian dilakukan pada semester genap. Subjek penelitian pada penelitian ini yaitu mahasiswa yang mengikuti mata kuliah geometri analitik yang berjumlah 31 orang mahasiswa.

Pada penelitian ini digunakan dua teknik pengumpulan data yaitu dengan angket dan tes. Angket digunakan untuk mengetahui disposisi matematika kemampuan disposisi mahasiswa. Tes digunakan untuk mengetahui level berfikir tingkat tinggi pada mahasiswa.

Teknik pengumpulan data yang pertama adalah tes. Hasil tes digunakan untuk mengetahui perbedaan tingkat berfikir mahasiswa. Pada penelitian tingkat berfikir yang dimaksud yaitu higher order thinking dan lower order thinking. Tes hasil belajar ini terdiri dari 8 butir soal yang dibuat berdasarkan indikator pencapaian kompetensi dan berada pada level tiga teratas taksonomi Bloom.

Teknik pengumpulan data yang kedua adalah angket. Hasil analisis dari angket digunakan untuk mengetahui disposisi matematika dominan yang dimiliki oleh mahasiswa yang memiliki kemampuan Higher Order Thinking. Indikator-indikator Disposisi dalam penelitian ini adalah 1) Percaya diri dalam menggunakan matematika untuk menyelesaikan masalah, mengkomunikasikan ide-ide matematis, dan memberikan argumentasi; 2) Berpikir fleksibel dalam mengeksplorasi ide-ide matematis dan mencoba metode alternatif dalam menyelesaikan masalah. 3) Gigih dalam mengerjakan tugas matematika 4) Berminat, memiliki keingintahuan (curiosity), dan memiliki daya cipta (inventiveness) dalam aktivitas bermatematika; 5) Memonitor dan merefleksi pemikiran dan kinerja; 6) Menghargai aplikasi matematika pada disiplin ilmu lain atau dalam 
kehidupan sehari-hari;7) Mengapresiasi peran matematika sebagai alat dan sebagai bahasa.

Instrumen Penelitian sebelum digunakan sebagai alat ukur penelitian dilakukan uji coba. Pada tes dilakukan uji coba meliputi uji validitas, reliabilitas, tingkat kesukaran dan daya pembeda. Uji coba instrument dilakukan untuk memperoleh alat ukur yang tepat. Uji coba yang dilakukan yaitu uji validitas, uji reliabilitas, daya beda dan tingkat kesukaran. Uji validitas bertujuan untuk mengetahui item soal tes hasil belajar valid atau tidak. Sedangkan uji reliabilitas digunakan untuk mengetahui item soal tes hasil belajar reliabel atau tidak. Hasil uji validitas dan uji reliabilitas digunakan sebagai pedoman untuk melakukan revisi terhadap item-item tes hasil belajar.

Uji coba instrument yang pertama yaitu validitas. Arikunto (2010: 211) menyatakan bahwa validitas adalah suatu ukuran yang menunjukkan tingkat-tingkat kevalidan atau kesahihan sesuatu instrumen. Pada penelitian ini soal berdasarkan level tiga teratas taksonomi Bloom akan diuji cobakan. Uji coba instrument yang kedua adalah reliabilitas. Soal pada penelitian ini akan diuji reliabilitas. Koefisien reliabilitas suatu tes bentuk uraian dapat ditaksir dengan menggunakan rumus Spearman Brown (Sugiyono, 2012 : 131). Penafsiran terhadap nilai ri (koefisien reliabilitas) yang diperoleh, maka nilai ri yang diperoleh dikorelasikan dengan rtabel. Apabila ri lebih dari rtabel maka soal akan dikatakan reliabel.

Uji coba instrumen yang ketiga yaitu menghitung indeks tingkat kesukaran soal. Uji ini untuk mengetahui level tingkat kesukaran. Level tersebut yaitu mudah, sedang, sukar dan sangat sukar. Uji coba yang keempat adalah menguji daya pembeda soal adalah kemampuan suatu soal untuk membedakan antara mahasiswa yang pandai (berkemampuan tinggi) dengan mahasiswa yang tidak pandai (berkemampuan rendah). Angka yang menunjukkan besarnya daya pembeda disebut indeks diskriminasi (D). Kriteria tes tiga teratas taksonomi Bloom dikatakan mempunyai daya pembeda baik jika nilai $\mathrm{D} \geq 0,40$ atau kategori soal diterima dengan baik.

Soal yang memenuhi empat kriteria akan digunakan sebagai tes untuk mengetahui perbedaan kemampuan berfikir pada mahasiswa. Setelah uji instrument maka dilakukan uji prasyarat. Uji prasyarat yaitu uji normalitas dan homogenitas.

Uji normalitas digunakan untuk mengetahui apakah data berdistribusi normal atau tidak. Selain menggunakan uji normalitas dengan Chi kuadrat, melakukan uji normalitas 
dapat menggunakan SPSS 16 berdasarkan nilai Signifikansi (Sig) pada kolom Kolmogorof-Smirnov (Sukestiyarno, 2012). Jika nilai sig > 0,05 maka data berdistribusi normal. Sedangkan uji homogenitas Menurut (Supriadi, 2014:142) pengujian homogen dilakukan dalam rangka menguji kesamaan varians setiap kelompok data

Uji hipotesis dilakukan setelah uji prasyarat dilaksanakan. Uji-t dilakukan jika data yang dianalisis berdistribusi normal dan homogen. Jika data yang dianalisis berdistribusi normal tetapi tidak homogen, maka digunakan uji-t'. Jika data yang dianalisis tidak berdistribusi normal dan tidak homogen, maka digunakan uji statistik nonparametrik yaitu MannWhitney-U. Uji-t dilakukan jika kedua pengujian persyaratan analisis data terpenuhi. Adapun rumusan hipotesis dalam bentuk kalimat sebagai berikut:

$$
H_{0}: \mu_{1}=\mu_{2}
$$

Mahasiswa yang berkemampuan Higher Order Thinking sama dengan disposisi matematika yang berkemampuan Lower Order Thinking.

$$
H_{a}: \mu_{1} \neq \mu_{2}
$$

Mahasiswa yang berkemampuan Higher Order Thinking lebih baik disposisi matematika yang berkemampuan Lower Order Thinking.

Keterangan:

$\mu_{1}=$ Rerata nilai skala mahasiswa yang berkemampuan Higher Order Tkinking $\mu_{2}=$ Rerata nilai skala mahasiswa yang berkemampuan Lower Order Thinking

Pengujian perbedaan rerata post-test menggunakan Independent samples $\mathrm{T}$ test dengan taraf signifikansi $\alpha=0,05$, maka kriteria pengambilan keputusannya adalah jika nilai signifikansi $\geq 0,05$ maka $H_{0}$ diterima, sedangkan jika nilai signifikansi $<0,05$ maka $H_{0}$ ditolak. Kemudian secara kualitatif dilakukan perhitungan prosentasi disposisi matematika. Tujuan memprosesntasekan hasil angket untuk memetakan disposisi yang dominan pada mahasiswa yang berfikir tingkat tinggi.

\section{HASIL DAN PEMBAHASAN}

Universitas Muhammadiyah Cirebon (UMC) merupakan salah satu universitas swasta yang berada di Cirebon. Salah satu Fakultas yang berada di UMC yaitu fakultas 
keguruan dan ilmu kependidikan. Fakultas keguruan dan ilmu pendidikan menaungi beberapa program studi (Prodi) yaitu prodi pendidikan matematika, prodi PGSD, prodi pendidikan kimia, prodi pendidikan IPA, Prodi pendidikan bahasa inggris. Prodi tempat melakukan penelitian ini yaitu pendidikan matematika. Objek penelitian yaitu mahasiswa yang mengikuti mata kuliah geometri analitik.

Prodi yang menjadi pendidikan matematika. Adapun variable yang akan diteliti yaitu percaya diri dalam menggunakan matematika untuk menyelesaikan masalah, mengkomunikasikan ide-ide matematis dan memberikan argumentasi, berpikir fleksibel dalam mengeksplorasi ide-ide matematis dan mencoba metode alternatif dalam menyelesaikan masala, gigih dalam mengerjakan tugas matematika, berminat, memiliki keingintahuan, dan memiliki daya cipta dalam aktivitas bermatematika, memonitor dan merefleksi pemikiran dan kinerja, menghargai aplikasi matematika pada disiplin ilmu lain atau dalam kehidupan sehari-hari, mengapresiasi peran matematika sebagai alat dan sebagai bahas. Sedangkan dimensi pada HOT yang diteliti yaitu analisis, evaluasi dan kreasi

Deskripsi karakteristik subjek penelitian disajikan tabel berikut.

Tabel 1

Rekapitulasi Data Subjek penelitian

\begin{tabular}{|c|l|c|c|}
\hline \multirow{2}{*}{ No } & \multirow{2}{*}{ Karakteristik Responden } & \multicolumn{2}{|c|}{ Keadaan } \\
\cline { 3 - 4 } & & Jumlah & Prosentase \\
\hline 1 & Jenis kelamin & 9 & \\
& a. Pria & 22 & $29 \%$ \\
& b. Wanita & $71 \%$ \\
\hline
\end{tabular}

Sumber : data diolah (2017)

Selain itu hasil uji statistik yang diperoleh dari angket disajikan sebagai berikut.

Tabel 2

Hasil grup statistics

Group Statistics

\begin{tabular}{|c|c|c|c|c|}
\hline Kelas & $\mathrm{N}$ & Mean & $\begin{array}{c}\text { Std. } \\
\text { Deviation }\end{array}$ & $\begin{array}{l}\text { Std. Error } \\
\text { Mean }\end{array}$ \\
\hline Disposisi & 17 & 71.06 & 6.134 & 1.488 \\
\hline & 14 & 65.18 & 6.601 & 1.764 \\
\hline
\end{tabular}


Berikut rekapitulasi hasil uji coba Instrumen disajikan table 3 sebagai berikut.

Table 3

Hasil uji instrumen

\begin{tabular}{|c|c|c|c|c|c|c|}
\hline $\begin{array}{c}\text { No } \\
\text { Soal }\end{array}$ & $\begin{array}{c}\text { Daya } \\
\text { Pembeda }\end{array}$ & Kriteria & $\begin{array}{c}\text { Indeks } \\
\text { Kesukaran }\end{array}$ & $\begin{array}{c}\text { Inter- } \\
\text { pretas } \\
\mathrm{i}\end{array}$ & $\begin{array}{c}\text { Vali } \\
\text { ditas }\end{array}$ & $\begin{array}{c}\text { Inter- } \\
\text { pretas } \\
\mathrm{i}\end{array}$ \\
\hline Soal 1 & 0,07 & Jelek & 0,96 & $\begin{array}{c}\text { Muda } \\
\mathrm{h}\end{array}$ & $\begin{array}{c}0,40 \\
1\end{array}$ & Valid \\
\hline Soal 2 & $-0,06$ & Jelek & 0,78 & $\begin{array}{c}\text { Muda } \\
\mathrm{h}\end{array}$ & $\begin{array}{c}0,14 \\
7\end{array}$ & $\begin{array}{c}\text { Tidak } \\
\text { Valid }\end{array}$ \\
\hline Soal 3 & 0,54 & Baik & 0,75 & $\begin{array}{c}\text { Muda } \\
\mathrm{h}\end{array}$ & $\begin{array}{c}0,58 \\
6\end{array}$ & Valid \\
\hline Soal 4 & 0,42 & Baik & 0,69 & $\begin{array}{c}\text { Sedan } \\
\mathrm{g}\end{array}$ & $\begin{array}{c}0,51 \\
8\end{array}$ & Valid \\
\hline Soal 5 & 0,26 & Cukup & 0,14 & $\begin{array}{c}\text { Sukar } \\
0,63 \\
5\end{array}$ & Valid \\
\hline Soal 6 & 0,28 & Cukup & 0,15 & $\begin{array}{c}\text { Sukar } \\
0,67 \\
7\end{array}$ & Valid \\
\hline Soal 7 & 0,30 & Cukup & 0,15 & Sukar & $\begin{array}{c}0,69 \\
0\end{array}$ & Valid \\
\hline Soal 8 & 0,33 & Cukup & 0,20 & Sukar & $\begin{array}{c}0,78 \\
9\end{array}$ & Valid \\
\hline Soal 9 & 0,25 & Cukup & 0,13 & Sukar & $\begin{array}{c}0,77 \\
1\end{array}$ & Valid \\
\hline $\begin{array}{c}\text { Soal } \\
10\end{array}$ & 0,82 & $\begin{array}{c}\text { Baik } \\
\text { Sekali }\end{array}$ & 0,53 & $\begin{array}{c}\text { Sedan } \\
\text { g }\end{array}$ & $\begin{array}{c}0,70 \\
7\end{array}$ & Valid \\
\hline
\end{tabular}

Sumber : data diolah (2017)

Hasil uji coba reliabilitas diperoleh nilai alpha sebesar 0,800 artinya soal yang diujikan memiliki tingkat reliabilitas tinggi. Berdasarkan hasil analisis uji coba instrument maka soal yang akan digunakan untuk instrument penelitian yaitu soal no.3, 4, 5, 6, 7, 8, 9 dan 10 .

Data yang diperoleh berdasarkan hasil tes diuj i normalitasnya. Hasil Uji Normalitas disajikan table 4 sebagai berikut. 
Tabel 4

Tests of Normality

\begin{tabular}{|r|r|r|r|r|r|r|}
\hline & \multicolumn{3}{|c|}{ Kolmogorov-Smirnov $^{\mathrm{a}}$} & \multicolumn{3}{c|}{ Shapiro-Wilk } \\
\cline { 2 - 7 } & Statistic & \multicolumn{1}{c|}{ Df } & \multicolumn{1}{c|}{ Sig. } & Statistic & df & \multicolumn{1}{c|}{ Sig. } \\
\hline Disposisi & .101 & 31 & $.200^{*}$ & .933 & 31 & .053 \\
\hline
\end{tabular}

a. Lilliefors Significance Correction

*. This is a lower bound of the true significance.

Berdasarkan hasil uji normalitas diperoleh nilai sig $=0.200$. senilai dengan $20 \%$. Jika dibandingkan maka 20\% > 5\% maka Ho diterima artinya nilai skala disposisi matematika diterima. Nilai sig yang digunakan yaitu pada uji Kolmogorov smirnov karena sampel kurang dari 30. Normalitas dari uji normalitas dapat diperkuat dengan melihat Q-Q plot pada gambar berikut.

\section{Gambar 5 \\ Q-Q plot}

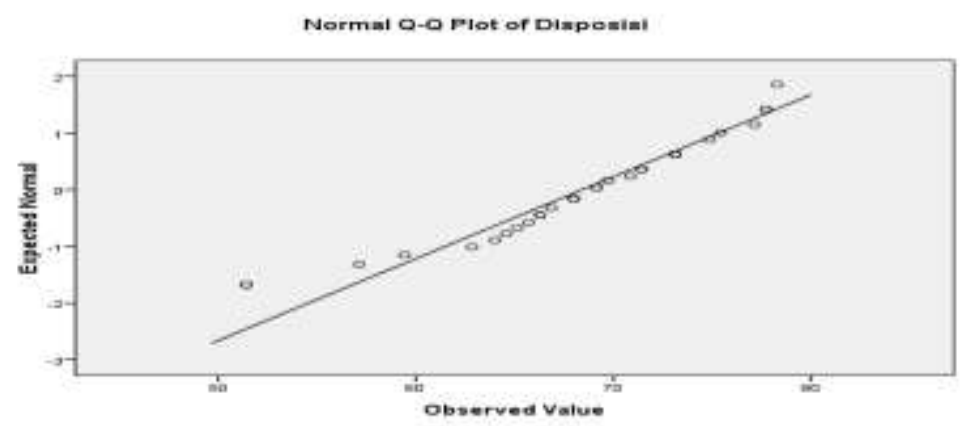

Berdasarkan gambar dapat dilihat kedudukan titik-titik. Garis yang ditunjukan gambar merupakan garis normal. Jika diperhatikan kedudukan titik mendekati atau tepat di garis normal. Dan letak box plot berada di posisi tengah. Hal ini menunjukkan bahwa data bersifat normal.

Uji homogenitas dilakukan setelah melakukan uji normalitas. Hasil uji yang dilakukan pada Uji Homogenitas disajikan pada table berikut. 
Tabel 6

Independent Samples Test

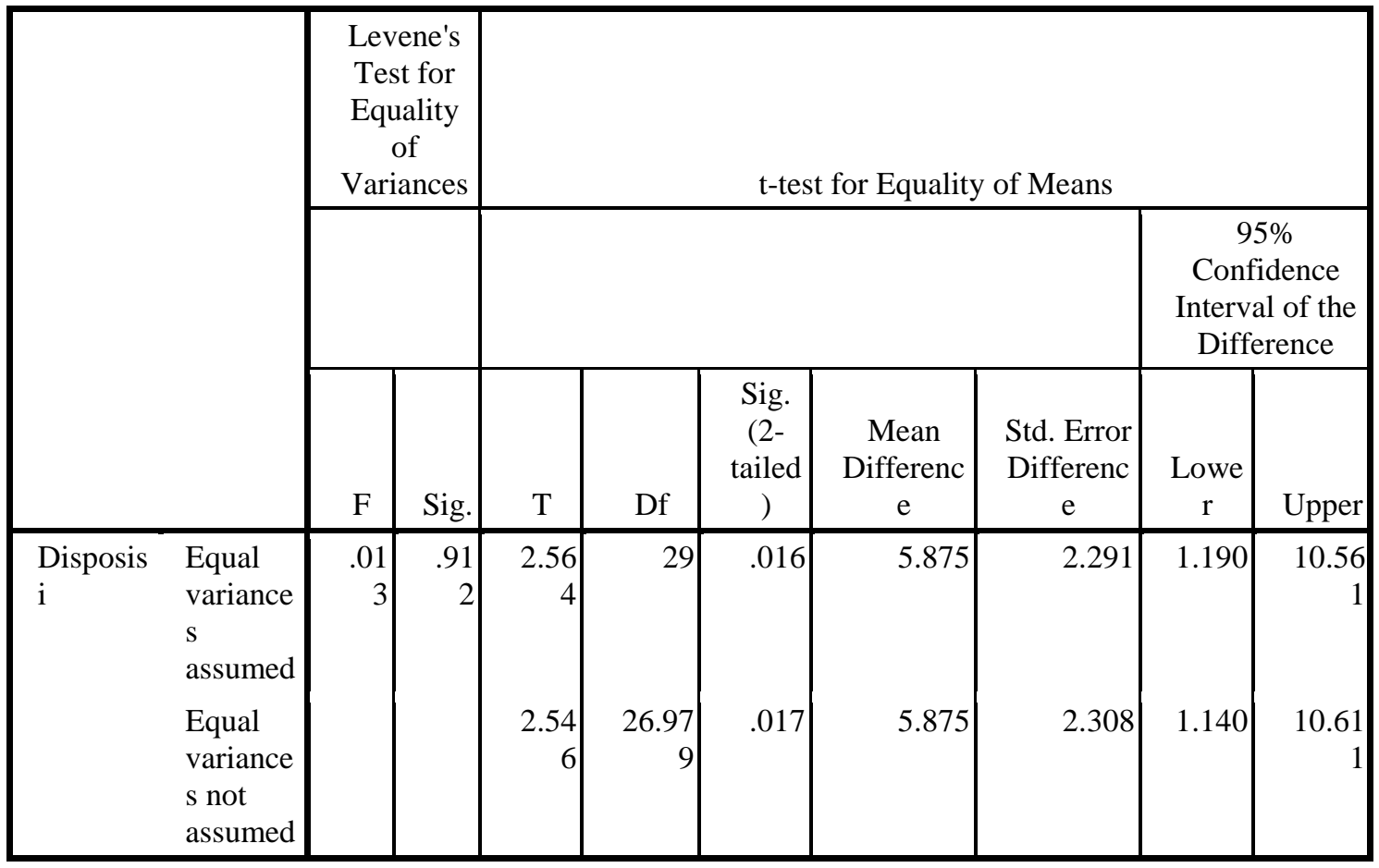

Berdasarkan uji homogenitas yaitu diatas 5\% nilai signifikasinya masing-masing item maka data tersebut homogen. Sig pada table menunjukkan 0.912 senilai dengan 91.2 $\%$. Jika dibandingakan maka $91.2 \%>5 \%$ artinya kedua kelompok mempunyai varian sama (homogeny).

Nilai t nilai sig 0.016 senilai dengan $1.6 \%$. jika dibandingkan maka $1.6 \%<5 \%$ maka Ho ditolak dan $\mathrm{H} 1$ diterima. Jadi terdapat perbedaan rerata pada dua sample. Jika dilihat pada group statistic diperoleh perbedaan antara kelompok 1 dan 2. Selain diuji secara statistik parametric, data diuji berdasarkan statistic deskriptif. Rata-rata hasil angket setiap indikator dianalisis. Berikut hasil analisis rata-rata indikator instumen disajikan gambar sebagai berikut. 


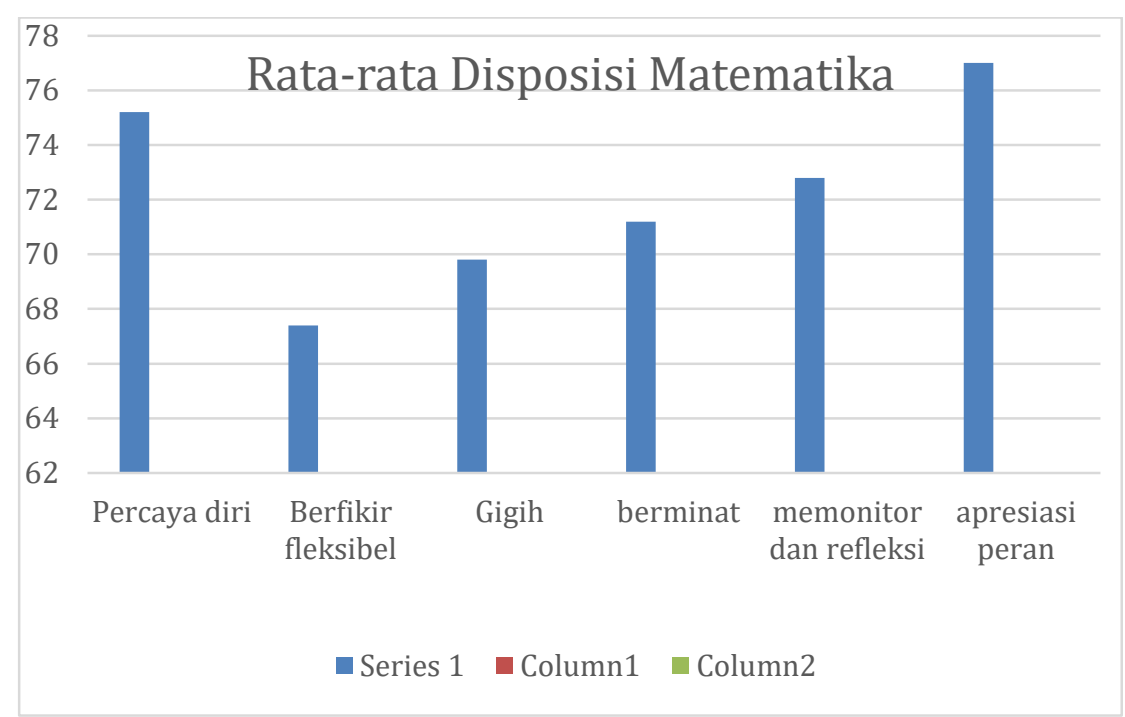

Gambar 1

Grafik Hasil Analisis Rata-Rata Indikator Instumen

Gambar 1 merupakan rata-rata pada mahasiswa yang memiliki kemampuan higher order thinking. Mahasiswa dengan kemampuan HOT memiliki disposisi yang dominan. Disposisi yang dominan yaitu percaya diri, dan memonitor peran. Sedangkan yang palin rendah yaitu berfikir fleksibel.

Berdasarkan analisa menggunakan uji banding diperoleh yang dilakukan dengan taraf signifikansi sig $1.6 \%$, sehingga diperoleh kesimpulan antar mahasiswa yang memiliki kemapuan LOT dan HOT memiliki perbedaan. Hasil analisis data menunjukkan bahwa terdapat perbedaan disposisi matematika berdasarkan tingkat berfikir mahasiswa berdasarkan HOT. mahasiswa yang berfikir tingkat tinggi memiliki disposisi matematika yang lebih baik dibandingkan dengan siswa yang memiliki tingkat lower order thinking.

Hasil penelitian disajikan dalam bentuk narasi. Jika hasil penelitian disajikan dalam bentuk tabel, gambar, atau grafik harus ditambahkan deskripsinya dalam bentuk narasi. Judul tabel berada di atas table, sedangkan judul grafik atau gambar ditaruh di bawah serta tidak dituliskan dalam dua kolom.

Pembahasan difokuskan pada pengaitan data dan hasil analisisnya dengan permasalahan atau tujuan penelitian dan konteks teoretis.Temuan berupa kenyataan di lapangan dikaitkan dengan hasil-hasil penelitian sebelumnya atau dengan teori yang sudah ada. 


\section{SIMPULAN DAN SARAN}

Kesimpulan Disposisi matematika yang lebih dominan yaitu kepercayaan diri dan aprsiasi peran.

Berdasarkan hasil penelitian dapat disimpulkan:

1. Diperoleh sig sebesar $1,6 \%$. Hasil analisis data menunjukkan bahwa terdapat perbedaan disposisi matematika berdasarkan tingkat berfikir mahasiswa berdasarkan HOT. mahasiswa yang berfikir tingkat tinggi memiliki disposisi matematika yang lebih baik dibandingkan dengan siswa yang memiliki tingkat lower order thinking.

2. Disposisi matematika yang lebih dominan yaitu kepercayaan diri dan apresiasi peran.

Saran untuk peneliti lainnya yaitu.

1. Melakukan pada sampel atau populasi yang lebih luas.

2. Dibuat panduan geometri analitik berdasarkan berfikir tingkat tinggi yang meletakkan disposisi mahasiswa pada penyususan buku atau modul

\section{DAFTAR RUJUKAN}

Anderson dan Krathwohl. 2002. A Taxonomy for Learning, Teaching and Assessing. New York : Longman.

Arikunto, S. 2010. Dasar-Dasar Evaluas Pendidikani. Jakarta : Bumi Aksara.

Beck, P. 2005. Mathematics Assesment A Practical Handbook for Grades 6-8. USA: NCTM.

Bookhart, S., M., 2010. How to Assess Higher Order Thinking Skills in Your Classroom. Virginia: ASCD.

Maharaj, A., \& Wagh, V. (2016). Formulating Tasks to Develop HOTS for First-Year Calculus Based on Brookhart Abilities. South African Journal of Science, 112(11), 1-6.

Morris, K, et al. 2009. "Mathematical Knowledge for Teaching in Planning and Evaluating Instruction: What Can Preservice Teachers Learn?" Journal for Research Mathematics Education. Volume 40. Hal. 479-492.

Resnick., Lauren. 1987. Education and Learning to Think. Washington D.C : 1987.

Sugiyono. 2012. Metode Penelitian Pendidikan (Pendekatan, Kuantitatif, Kualitatif, dan .$R \& D$. Bandung: Alfabeta.

Sukestiyarno. 2012. Olah Data Penelitian Berbantuan SPSS. Semarang: Universitas Negeri Semarang.

Supriyadi. 2014. SPSS dan AMOS Statistical Data Analysis. Jakarta: In Media 